\title{
Intraocular pressure rise is predictive of vision improvement after intravitreal triamcinolone acetonide for diabetic macular oedema: a retrospective analysis of data from a randomised controlled trial
}

Roderick F O'Day ${ }^{1 *}$, Daniel Barthelmes ${ }^{1}$, Meidong Zhu' ${ }^{1}$, Tien Y Wong ${ }^{2,3}$, lan L McAllister ${ }^{4}$, Jennifer J Arnold ${ }^{5}$ and Mark C Gillies ${ }^{1}$

\begin{abstract}
Background: Intravitreal triamcinolone acetonide (IVTA) is an effective treatment for recalcitrant diabetic macular oedema (DMO). It has been shown to improve vision with benefits persisting up to five years. The most common initial side effect of IVTA treatment is rise in intraocular pressure, occurring in approximately $50 \%$ of patients within the first 6 months of treatment. We evaluated whether there is a correlation between the development of intraocular pressure rise and improvement in vision.

Methods: Analysis of individual data from 33 eyes of 33 participants treated with IVTA for DMO from a prospective, randomised, double-masked, placebo controlled trial. The degree of intraocular pressure (IOP) rise was correlated with improvement in best-corrected visual acuity (BCVA) at 1 and 6 months.
\end{abstract}

Results: The proportion of eyes gaining 5 or more logMAR letters was higher in eyes with greater IOP rise $(p=0.044)$. Better absolute improvement in BCVA at 6 months $(p=0.045)$ was also found in eyes with greater IOP rise. Regression analyses revealed a correlation between IOP rise of 10 or more $\mathrm{mmHg}$ and absolute BCVA improvement at 6 months (odds ratio 1.22, 95\% confidence interval 1.01-1.48, $p=0.039$ ), but not at 1 month.

Conclusions: IOP rise and vision improvement appear to be correlated following IVTA for DMO, suggesting that the mechanisms that cause both may be linked.

Trial Registration: Clinical trials.gov NCT00167518, September 5, 2005.

Keywords: Intravitreal triamcinolone, Diabetic macular oedema, Vision improvement, Intraocular pressure rise, Adverse events, Efficacy

\section{Background}

The treatment of diabetic macular oedema (DMO), the commonest cause of vision loss in people with diabetes, is rapidly evolving [1]. The past ten years have seen a progressive shift away from laser photocoagulation therapy with the emergence of new pharmacotherapeutic

\footnotetext{
* Correspondence: roderick.oday@gmail.com

${ }^{1}$ Clinical Ophthalmology \& Eye Health, The University of Sydney, Sydney, Australia

Full list of author information is available at the end of the article
}

approaches. Much of the recent focus has been on intravitreal inhibitors of vascular endothelial growth factor (VEGF). These are rapidly becoming the standard of care for diffuse DMO [2]. VEGF inhibitors are generally well tolerated, however, potentially significant systemic and ocular side effects have not been comprehensively excluded [3,4]. In particular, it has been suggested that VEGF may play a neuroprotective role, the inhibition of which may lead to loss of vision in the long-term [5].

Intravitreal triamcinolone (IVTA) is another proven treatment for recalcitrant DMO with well-known side-effects
C Biomed Central

(c) 2014 O'Day et al.; licensee BioMed Central Ltd. This is an Open Access article distributed under the terms of the Creative Commons Attribution License (http://creativecommons.org/licenses/by/2.0), which permits unrestricted use, distribution, and reproduction in any medium, provided the original work is properly credited. 
[6-12]. In patients with persistent DMO despite laser treatment, intravitreal injections of triamcinolone acetonide were shown to improve vision and reduce macular thickness with benefits persisting up to five years [6-8]. In that study, IVTA treatment doubled the chance of visual acuity improvement and halved the chance of deterioration in eyes with advanced DMO [6-8].

The ocular safety of IVTA treatment has been thoroughly explored [6-8,13-16]. The most common adverse events of IVTA treatment are intraocular pressure (IOP) rise and accelerated cataract formation, particularly posterior subcapsular cataract. Reported rates of IOP rise differ; in our study approximately $50 \%$ of eyes had an IOP rise of 5 or more $\mathrm{mmHg}$ within the first six months of IVTA treatment [6-8]. IOP rise has been shown to be significantly associated with cataract progression, suggesting that these steroid-related adverse events may have similar aetiologies, for example genetic polymorphisms in the steroid receptor [15]. In this study, we analysed whether IOP rise was linked with visual acuity improvement using data from the Triamcinolone for Diabetic Macular Oedema (TDMO) study [6-8]. If so, this would suggest that the mechanisms of IOP rise and vision improvement after IVTA for DMO are similar and may help to further advance our understanding of how IVTA acts on macular oedema.

\section{Methods}

This analysis is based on data from the TDMO study, which was the first major prospective, randomised, double masked, placebo-controlled clinical trial to test the hypothesis that IVTA safely improves visual acuity in eyes with advanced DMO over 2 years [6-8]. For the TDMO study, patients were recruited from a major tertiary referral centre. Inclusion criteria were persistent diabetic macular oedema involving the central fovea persisting three months or more after adequate laser treatment and best corrected visual acuity (BCVA) in the affected eye of $6 / 9$ or worse [6-8]. A total of 69 eyes were enrolled in the study, 4 of which were lost to follow up within the first three months. Of the remaining 65 eyes, 33 received triamcinolone treatment and are the subject of the present analysis. At baseline eyes received either a $4 \mathrm{mg}$ IVTA injection $-0.1 \mathrm{ml}$ of Kenacort 40 (40 mg/ml triamcinolone acetonide; Bristol-Myers Squibb, Noble Park, Australia) - or a sham-injection with subconjunctival saline. The TDMO study was conducted in accordance with the Declaration of Helsinki and was approved by the South Eastern Sydney Area Health Service and University of Sydney research ethics committees. Written informed consent was obtained from all patients prior to treatment assignment.

For the purpose of this analysis, the visual acuity outcomes were (A) change in number of letters read on a
Logarithm of the Minimal Angle of Resolution (LogMAR) chart and (B) proportion of eyes that had improved vision by 5 or more LogMAR letters. Both were assessed as difference between baseline and 1 or 6 months. During this time all eyes received a single injection of IVTA. Change in IOP was defined as the difference between baseline and the highest IOP measured within 6 months after IVTA treatment. IOP was measured using Goldmann applanation tonometry. Various definitions of IOP rise are used in the literature including, absolute values $[17,18]$ percentage increase from baseline [19], and change from baseline [13-19]. No one definition has been universally adopted. For a descriptive analysis, we stratified eyes into three groups according to degree of change in IOP - less than a $5 \mathrm{mmHg}$ increase, increase by $5 \mathrm{mmHg}$ or more but less than $10 \mathrm{mmHg}$ and increase by $10 \mathrm{mmHg}$ or more - from baseline. Intraocular pressure and VA data at 1 and 6 months were compared to baseline. This enabled us to stratify our analyses to effectively assess eyes that have a moderate intraocular pressure response, i.e. those gaining 5 or more, but less than $10 \mathrm{mmHg}$, and those that have a strong intraocular pressure response, i.e. those gaining 10 or more $\mathrm{mmHg}$. For the regression analysis, eyes were allocated to two groups: less than $10 \mathrm{mmHg}$ in increase and $10 \mathrm{mmHg}$ or more increase.

\section{Statistical analysis}

Data are presented as mean \pm standard deviation (SD) when normally distributed or as median and [interquartile range] if not. Normality was assessed using the ShapiroWilks test. The homogeneity of variances between two groups was assessed using Levene's test. Differences in continuous variables between multiple groups were compared using a one-way ANOVA or the Kruskal-Wallis for normally and not normally distributed data, respectively. In cases of significant ANOVA results, post-hoc testing was performed. If equal variances could be assumed, a Bonferroni correction was applied. If not, Dunn's test was applied. Differences in proportions between three groups were analysed using Fisher's exact test with the FreemanHalton extension. Correcting for baseline characteristics, two separate binary logistic regression models were performed to examine whether improvement in vision at 1 (model A) and 6 months (model B) was predictive of IOP increase. Eyes with missing values were excluded from these analyses. The dependent variable was IOP rise within six months of IVTA injection. The independent variables were change in BCVA (continuous variable) at 1 or 6 months, age at baseline (continuous variable), gender (binary variable) and phakic status at baseline (binary variable). Collinearity was examined by calculating tolerance and variance inflation factor (VIF).

A priori a $p$ value of $<0.05$ was defined as statistically significant. All data were analysed using a commercially 
available software package (PASW 21, SPSS Inc., Chicago, IL, USA).

\section{Results}

Of the 33 eyes treated with IVTA in the TDMO study, $6(18 \%)$ were pseudophakic at baseline and $15(45 \%)$ were female. The mean age of patients at baseline was $63.27 \pm 10.10$ years and median glycosylated haemoglobin (HbA1c) was 7.7 [5.7 to 9.5] percent. The mean central macular thickness (CMT) was $444 \pm 125$ micrometres, IOP was $16.55 \pm 2.56 \mathrm{mmHg}$ and median BCVA was 64.0 [52.5 to 70.0 ] letters $\log$ Mar.

Table 1 shows the baseline characteristics of eyes treated with IVTA stratified with respect to intraocular pressure response. There was no significant difference in the measured baseline characteristics - age, gender, HbA1c, phakic status, IOP, BCVA and CMT - between the groups classified according to degree of IOP rise.

Data on IOP rise was available for all eyes. BCVA data was not available for 4 eyes at the 6 month follow-up, but was otherwise complete.

\section{IOP rise and visual outcomes}

Seventeen eyes (52\%) had an IOP change from baseline of less than a $5 \mathrm{mmHg}$ or more increase, $8(24 \%)$ had a rise of 5 or more but less than $10 \mathrm{mmHg}$ and $8(24 \%)$ had a rise of 10 or more $\mathrm{mmHg}$. Eyes that had greater IOP rise had significantly greater chance of having an improvement in vision by 5 or more letters at 1 month $(p=0.044$, Table 2$)$ and there was a trend for these eyes to have better absolute improvement in BCVA $(p=0.058$, Table 2). At 6 months, eyes that exhibited greater IOP rise had better absolute improvement in BCVA $(p=0.045$, Table 2), but the proportion of eyes improving by 5 of more letters was not significant (Table 2).

Regression analyses revealed a correlation between IOP rise of 10 or more mmHg and absolute vision improvement at 6 months (odds ratio 1.22, 95\% confidence interval 1.01-1.48, $p=0.039$, Table 3 ), but not at 1 month. Baseline age, gender and phakic status did not predict IOP rise by 10 or more $\mathrm{mmHg}$ (Table 3 ).

\section{Discussion}

This analysis examined the relationship between the development of adverse events and visual outcomes after IVTA treatment in order to gain further insights into its mechanism of action in treating DMO. We found a correlation between IOP rise and vision improvement at two time points in the first 6 months after a single treatment with IVTA for DMO. It seems that the greater the IOP rise, the more likely eyes are to improve in vision, at least in the short term.

Significant research has examined the clinical application of glucocorticoids in inflammatory and oedematous diseases of the eye, however, the mechanisms of steroidinduced changes are yet to be fully elucidated. Steroidinduced IOP rise is thought to be due to activation of glucocorticoid receptors in the trabecular meshwork $[20,21]$. It has been suggested that polymorphisms of the Myocilin gene, which is upregulated by glucocorticoids, may be responsible for steroid-induced IOP rise [22]. Ultimately, steroids cause biochemical and ultrastructural changes to the trabecular meshwork resulting in greater resistance in the aqueous humour outflow tract $[23,24]$. Less is known about the mechanism of vision improvement by IVTA than that of IOP rise. It is likely to be more complex than reduction in macular thickness alone, as evidenced by a lack of a correlation between these two clinical outcomes [25]. It has been proposed that improvement in glial and neuronal function may explain the improvement in vision following IVTA treatment [26-28]. This is consistent with recent clinical findings that there is a strong link between photoreceptor integrity and visual acuity outcomes in patients treated with IVTA for DMO [29].

A strong correlation between IOP rise and cataract formation has previously been shown, suggesting a common

Table 1 Baseline characteristics of 33 eyes treated with IVTA stratified with respect of change in IOP from baseline

\begin{tabular}{|c|c|c|c|c|}
\hline Characteristic & $\begin{array}{l}\text { IOP change }<5 \mathrm{mmHg} \text { rise } \\
\qquad(\mathrm{n}=17)\end{array}$ & $\begin{array}{l}\text { IOP rise } 5-9 \mathrm{mmHg} \\
\qquad(\mathrm{n}=8)\end{array}$ & $\begin{array}{l}\text { IOP rise } \geq 10 \mathrm{mmHg} \\
\qquad(\mathrm{n}=8)\end{array}$ & $P$ value \\
\hline Age $(y)$ & $63.8 \pm 8.4$ & $63.9 \pm 15.7$ & $61.5 \pm 7.2$ & 0.864 \\
\hline Gender, female (n) & $9(53 \%)$ & $4(50 \%)$ & $2(25 \%)$ & 0.440 \\
\hline $\mathrm{HbA} 1 c^{\mathrm{a}}$ & $7.9 \pm 1.2$ & $9.1 \pm 1.5$ & $8.2 \pm 1.5$ & 0.295 \\
\hline Phakia, pseudophakic (n) & $3(18 \%)$ & $2(25 \%)$ & $1(14 \%)$ & 0.862 \\
\hline IOP (mmHg) & $16.9 \pm 2.4$ & $15.8 \pm 3.1$ & $16.6 \pm 2.6$ & 0.600 \\
\hline BCVA (letters) & $60.1 \pm 14.0$ & $62.9 \pm 6.7$ & $58.5 \pm 12.7$ & 0.771 \\
\hline $\mathrm{CMT}(\mu \mathrm{m})^{\mathrm{b}}$ & $436 \pm 146$ & $443 \pm 132$ & $468 \pm 22$ & 0.916 \\
\hline
\end{tabular}

IVTA = intravitreal triamcinolone; IOP = intraocular pressure; BCVA = best-corrected visual acuity; $C M T$ = central macular thickness.

Values are mean \pm standard deviation or median with interquartile range shown in box brackets.

${ }^{a} \mathrm{n}=13,4$ and 7 for IOP rise $<5 \mathrm{mmHg}, 5-9 \mathrm{mmHg}$ and $\geq 10 \mathrm{mmHg}$, respectively.

${ }^{b} \mathrm{n}=12,5$ and 4 for IOP rise $<5 \mathrm{mmHg}, 5-9 \mathrm{mmHg}$ and $\geq 10 \mathrm{mmHg}$, respectively. 
Table 2 Vision improvement in eyes treated with IVTA stratified with respect to change in IOP from baseline

\begin{tabular}{|c|c|c|c|c|}
\hline & $\begin{array}{c}\text { IOP change }<5 \mathrm{mmHg} \text { rise } \\
\qquad(\mathrm{n}=17)\end{array}$ & $\begin{array}{l}\text { IOP rise } 5-9 \mathrm{mmHg} \\
\qquad(\mathrm{n}=8)\end{array}$ & $\begin{array}{l}\text { IOP rise } \geq 10 \mathrm{mmHg} \\
\qquad(\mathrm{n}=8)\end{array}$ & $P$ value \\
\hline \multicolumn{5}{|l|}{1 month } \\
\hline Gain in BCVA $\geq 5$ letters & $8(47 \%)$ & $2(25 \%)$ & $7(88 \%)$ & 0.044 \\
\hline Mean gain in visual acuity (letters) & $4.0[-0.5$ to 6.0$]$ & $3.0[0.0$ to 6.3$]$ & $6.5[5.3$ to 12.0$]$ & 0.058 \\
\hline \multicolumn{5}{|l|}{6 months } \\
\hline Gain in BCVA $\geq 5$ letters ${ }^{a}$ & $9(56 \%)$ & $3(43 \%)$ & $5(71 \%)$ & 0.561 \\
\hline Mean gain in visual acuity (letters) ${ }^{a}$ & $4.8 \pm 6.5$ & $1.4 \pm 7.4$ & $11.7 \pm 9.7$ & 0.045 \\
\hline
\end{tabular}

IVTA = intravitreal triamcinolone; IOP = intraocular pressure.

Values are mean \pm standard deviation or median with interquartile range shown in box brackets.

${ }^{a} \mathrm{n}=16,7$ and 7 for IOP rise $<5 \mathrm{mmHg}, 5-9 \mathrm{mmHg}$ and $\geq 10 \mathrm{mmHg}$, respectively.

mechanism to their formation, possibly through genetic polymorphisms of the common steroid receptor in the trabecular meshwork and lens epithelium [15,20,21,30]. We conducted the present analysis to see whether there was a similar correlation between IOP rise and visual outcomes after intraocular steroid therapy. Our results suggest that this is the case and that there may be a common mechanism for IOP rise and vision improvement. The correlation found in this analysis was not as strong as that between IOP rise and cataract formation [15]. This may be due to the small numbers available for analysis. Despite this, there was a statistically significant trend for eyes that had greater IOP rise to have good visual outcomes and the study that the data is derived from is of very high quality. The fact that the association between IOP rise and VA improvement could only be established for the 6 month VA outcomes may be related to the fact that in DMO, VA improvements occur slowly, especially in the patient group chosen for this study - patients with recalcitrant DMO.

Table 3 Predicting IOP rise of 10 or more $\mathbf{m m H G}$

\begin{tabular}{lccc}
\hline Predictor & Odds ratio & $\begin{array}{c}\mathbf{9 5 \%} \text { confidence } \\
\text { interval }\end{array}$ & P value \\
\hline $\mathbf{1}$ Month & 1.00 & $0.91-1.10$ & 0.972 \\
Baseline age & 2.61 & $0.39-17.62$ & 0.325 \\
Gender & 1.32 & $0.10-17.05$ & 0.831 \\
Baseline phakia & 1.13 & $0.96-1.33$ & 0.149 \\
$\begin{array}{l}\text { Mean gain in visual acuity at } \\
1 \text { month (letters) }\end{array}$ & & & 0.894 \\
$\mathbf{6}$ months & 0.99 & $0.87-1.14$ & 0.248 \\
Baseline age & 3.91 & $0.14-457.82$ & 0.316 \\
Gender & 7.94 & $1.01-1.48$ & 0.039 \\
Baseline phakia & 1.22 & & \\
Mean gain in visual acuity at & & & \\
6 months (letters) & & & \\
\hline
\end{tabular}

IVTA = intravitreal triamcinolone; $\mathrm{IOP}=$ intraocular pressure; $\mathrm{BCVA}=$ best corrected visual acuity.

Binary logistic regression analyses.
The major weakness of this retrospective analysis is the relatively small number of patients available. In theory, this would result in missing weak relationships. Our findings should be viewed positively in light number of patients analysed. The classifications of IOP rise we used were not prospectively defined. Analyses based on these are potentially subject to selection bias. None of the measured baseline characteristics were found to be statistically significantly different between the groups. We cannot be certain that unmeasured baseline characteristic influenced our results.

As well as potentially adding to our knowledge of the mechanisms of IVTA on macular oedema, this analysis has clinical implications. It seems that those eyes that have a high degree of IOP rise are more likely to have very good visual outcomes 6 months after treatment, with a mean improvement of 11.7 letters on an ETDRS scale found in our subjects. Concurrently, these eyes are at greater risk of developing posterior subcapsular cataract [15]. This adds further complexity to the harm/ benefit analysis the clinician must make in deciding whether to treat.

\section{Conclusions}

This analysis has revealed a positive relationship between the intraocular pressure rise and visual improvement following IVTA treatment for DMO, at least in the short term. This suggests that there may be a common mechanism to the development of these outcomes, which is yet to be elucidated. These eyes are concurrently at higher risk of developing posterior subcapsular cataract.

\footnotetext{
Competing interests

The authors declare that they have no competing interests.
}

Authors' contributions

MG conceived the current analysis. MG, MZ, JA, IMcA and T-YW conceived the original study and were involved in the data collection supervision. RO and DB performed the statistical analysis. RO, DB and MG drafted the manuscript. All authors read and approved the final manuscript. 


\section{Acknowledgments}

The Safety Monitoring Committee for both studies comprised: Jeremy Smith MB BS, FRANZCO (Chair), Paul Power BSc, Jie Jin Wang PhD.

There were no funding sources for the preparation of this manuscript.

\section{Author details}

${ }^{1}$ Clinical Ophthalmology \& Eye Health, The University of Sydney, Sydney, Australia. ${ }^{2}$ Singapore Eye Research Institute, National University of Singapore, Singapore, Singapore. ${ }^{3}$ Centre for Eye Research Australia, University of Melbourne, Melbourne, Australia. ${ }^{4}$ Lions Eye Institute, University of Western Australia, Perth, Australia. ${ }^{5}$ Marsden Eye Specialists, Sydney, Australia.

Received: 2 May 2013 Accepted: 25 September 2014

Published: 21 October 2014

\section{References}

1. Kohner E: Diabetic retinopathy. Clin Endocrinol Metab 1977, 6:345-375.

2. Giuliari GP: Diabetic retinopathy: current and new treatment options. Curr Diabetes Rev 2012, 8:32-41.

3. Schmucker C, Loke YK, Ehlken C, Agostini HT, Hansen LL, Antes G, Lelgemann M: Intravitreal becavizumab (Avastin) versus ranibuzumab (Lucentis) for the treatment of age-related macular degeneration: a safety review. Br J Ophthalmol 2011, 95:308-317.

4. Quaggin SE: Turning a blind eye to anti-VEGF toxicities. J Clin Invest 2012, [Epub ahead of print].

5. van Wijngararden $P$, Coster DJ, Williams KA: Inhibitors of ocular neovascularization: promises and potential problems. JAMA 2005, 293:1509-1513.

6. Sutter FK, Simpson JM, Gillies MC: Intravitreal triamcinolone for diabetic macular oedema that persists after laser treatment: three-month efficacy and safety results of a prospective, randomized, double-masked, placebo-controlled clinical trial. Ophthalmology 2004, 111:2044-2049.

7. Gillies MC, Sutter FK, Simpson JM, Larsson J, Ali H, Zhu M: Intravitreal triamcinolone for refractory diabetic macular oedema: two-year results of a double-masked, placebo-controlled, randomized clinical trial. Ophthalmology 2006, 113:1533-1538.

8. Gillies MC, Simpson JM, Gaston C, Hunt G, Ali H, Zhu M, Sutter F: Five-year results of a randomized clinical trial with open label extension of intravitreal triamcinolone for refractory diabetic macular oedema. Ophthalmology 2009, 116:2182-2187.

9. Gillies MC, McAllister IL, Zhu M, Wong W, Louis D, Arnold JJ, Wong TY. Pretreatment with intravitreal triamcinolone before laser for diabetic macular oedema: 6-month results of a randomized, placebo-controlled trial. Invest Ophthalmol Vis Sci 2010, 51:2322-2328.

10. Jonas JB, Kamppeter BA, Harder B, Vosmmerbaeumer U, Sauder G, Spandau UH: Intravitreal triamcinolone acetonide for diabetic macular oedema: a prospective, randomized study. J Ocul Phamacol Ther 2006, 22:200-207.

11. Massin P, Audren F, Haouchine B, Erginay A, Bergmann JF, Benosman R, Caulin C, Gaudric A: Intravitreal triamcinolone acetonide for diabetic diffuse macular oedema: Preliminary results of a prospective controlled trial. Ophthalmology 2004, 111:218-224.

12. Diabetic Retinopathy Clinical Research Network Ophthalmology: A randomized trial comparing intravitreal triamcinolone acetonide and focal/grid photocoagulation for diabetic macular oedema. Ophthalmology 2008, 115:1447-1459.

13. Gillies MC, Simpson JM, Billson FA, Luo W, Penfold P, Chua W, Mitchell P, Zhu M, Hunyor AB: Safety of an intravitreal injection of triamcinolone: results from a randomized clinical trial. Arch Ophthalmol 2004, 122:336-340.

14. Konstantopoulos A, Williams CP, Newsom RS, Luff AJ: Ocular morbidity associated with intravitreal triamcinolone acetonide. Eye (Lond) 2007, 21:317-320.

15. Gillies MC, Kuzniarz M, Craig J, Ball M, Luo W, Simpson J: Intravitreal triamcinolone-induced elevated intraocular pressure is associated with the development of posterior subcapsular cataract. Ophthalmology 2005, 112:139-143.

16. Jonas JB, Degenring RF, Kreissig I, Akkoyun I, Kamppeter BA: Intraocular pressure elevation after intravitreal triamcinolone acetonide injection. Ophthalmology 2005, 112:593-598.
17. Chae JB, Joe SG, Yang SJ, Lee JY, Kim J-G, Yoon TH: An increase in intraocular pressure after intravitreal steroid injection facilitates reduce of macular edema. Eye (Lond) 2012, 26:479-480.

18. Sonmez K, Ozturk F: Complications of intravitreal triamcinolone acetonide for macular edema and predictive factors for intraocular pressure elevation. Int J Ophthalmol 2012, 5:719-725.

19. Jonas J, Kreissig I, Degenring R: Intraocular pressure after intravitreal injection of triamcinolone acetonide. Br J Opthalmol 2003, 87:24-27.

20. Hernandez MR, Wenk EJ, Weinstein BI, Abumohor P, Podos SM, Dunn MW, Southren AL: Glucocorticoid target cells in human outflow pathway: autopsy and surgical specimens. Invest Ophthalmol Vis Sci 1983, 24:1612-1616.

21. Weinreb RN, Bloom E, Baxter JD, Alvarado J, Lan N, O'Donnell J, Polansky JR: Detection of glucocorticoid receptors in cultured human trabecular cells. Invest Ophthalmol Vis Sci 1981, 21:403-407.

22. Vijayasekaran S, McAllister IL, Morgan WH, Mendis KR, McMenamin PG, Cringle SJ, Yu DY: Intravitreal triamcinolone acetonide induced changes in the anterior segment in a pig model of branch retinal vein occlusion. Graefes Arch Clin Exp Ophthalmol 2011, 249:215-222.

23. Becker B, Mills DW: Corticosteroids and intraocular pressure. Arch Ophthalmol 1963, 70:500-507.

24. Johnson DH, Bradley JM, Ascott TS: The effect of dexamethasone on glycosaminoglycans of human trabecular meshwork in the perfusion organ culture. Invest Ophthalmol Vis Sci 1990, 31:2568-2571.

25. Larsson J, Zhu M, Sutter F, Gillies MC: Relation between reduction of foveal thickness and visual acuity in diabetic macular edema treated with intravitreal triamcinolone. Am J Ophthalmol 2005, 139:802-806.

26. Tretiach M, Madigan MC, Wen L, Gillies MC: Effect of muller cell co-culture on in vitro permeability of bovine retinal vascular endothelium in normoxic and hypoxic conditions. Neurosci Lett 2005, 378:160-165.

27. Wenzel A, Grimm C, Seeliger MW, Jaissle G, Hafezi F, Kretschmer R, Zrenner E, Remé CE: Prevention of photoreceptor apoptosis by activation of the glucocorticoid receptor. Invest Ophthalmol Vis Sci 2001, 42:1653-1659.

28. Edelman JL: Differentiating intraocular glucocorticoids. Ophthalmologica 2010, 224:25-30.

29. Shin HJ, Lee SH, Chung H, Kim HC: Association between photoreceptor integrity and visual outcome in diabetic macular edema. Graefes Arch Clin Exp Ophthalmol 2012, 250:61-70.

30. James ER, Robertson L, Ehlert E, Fitzgerald P, Droin N, Green DR: Presence of a transcriptionally active glucocorticoid receptor $a$ in lens epithelial cells. Invest Ophthalmol Vis Sci 2003, 44:5269-5276.

doi:10.1186/1471-2415-14-123

Cite this article as: O'Day et al:: Intraocular pressure rise is predictive of vision improvement after intravitreal triamcinolone acetonide for diabetic macular oedema: a retrospective analysis of data from a randomised controlled trial. BMC Ophthalmology 2014 14:123.

\section{Submit your next manuscript to BioMed Central and take full advantage of:}

- Convenient online submission

- Thorough peer review

- No space constraints or color figure charges

- Immediate publication on acceptance

- Inclusion in PubMed, CAS, Scopus and Google Scholar

- Research which is freely available for redistribution 